\title{
UTILIZATION OF SUSTAINED FINISHER DIETS CONTAINED ALTERNATIVE PROTEIN SOURCES AND LEVELS ON PERFORMANCE AND CARCASS TRAITS OF BROILERS
}

\author{
A. M. Khalifah'; A. A. El-Deek ${ }^{2}$; Mona Osman M² $^{\mathbf{2}}$ A. El-Komy'; and M. El-Shafey ${ }^{3}$ \\ ${ }^{1}$ Livestock dep., Arid Land Cultivating Res. Inst.- City of Sci. Res. and Tec. Applications. \\ ${ }^{2}$ Poult. Prod. Dep., Fac. of Agric. - Alexandria Univ. \\ ${ }^{3}$ Ismailia/Misr Comp. for Poult. Prod.
}

Corresponding author: Ayman Khalifah; Email: Ayman_khalifah2000@yahoo.com

\begin{abstract}
Received:11/03/2017
Accepted:26/03/2017

ABSTRACT: An experiment was conducted to study the effect of replacing soybean meal (SBM) with mix of corn gluten meal (CGM), sunflower meal (SFM) and distillers dried grains with solubles (DDGS) at (2.5, 5 and $7.5 \%$, respectively) with different protein levels $(21,20$ and 19\%) at finisher diets on live performance and carcass traits of broilers. A total of 432 day old Cobb 500 chicks were randomly distributed into 6 treatments at (19-35) days of age, each with three replicates, each replicate contains 24 chicks. The six treatments were: 1) control $21 \% \mathrm{CP}, 2)$ tested $21 \% \mathrm{CP}, 3$ ) control $20 \% \mathrm{CP}, 4)$ tested $20 \% \mathrm{CP}$, 5) control $19 \% \mathrm{CP}$ and 6) tested $19 \% \mathrm{CP}$. Control diets were based only on soybean meal (SBM) as a source of protein, while tested diets based on mix of (CGM, SFM and DDGS) beside SBM. At the end of experiment at 35 days of age, 5 broilers per treatment were slaughtered and evaluated for carcass traits. The results of this study have shown that feeding tested diets at 21 and $20 \%$ protein could be applied without any effect on performance or carcass traits when compared to the corresponding control diets. However, feeding $19 \%$ tested diet showed better performance than control $19 \%$ but with no significant difference between them. So, it can be concluded that mix of (CGM, DDGS and SFM) could be included up to $15 \%$ to replace soybean meal protein in broiler finisher diets at a CP level ranged between 19 and $21 \%$.
\end{abstract}

Keywords: Alternative ingredients - Performance - Finisher diets - Carcass traits. 
Khalifah, M. A. et al.

\section{INTRODUCTION}

Scarcity of feed ingredients and their high costs for poultry feeding is the main obstacle to poultry industry development in many countries, especially Egypt. From the nutrition point of view, protein is one of the very important nutrients in poultry diets and plays an important part in maintenance and reparation of tissues as well as it promotes proper growth and development performance (Chinrasri, 2004). The nonavailability of SBM at an economically viable price forces the use of alternate protein sources in poultry diets (Rao et al., 2006). Therefore, there is a movement within poultry industry to reduce its reliance on SBM as a protein source and replacing it with more sustainable alternatives (Hwangbo et al., 2009; and Tolimir et al., 2010). Coming up with alternative protein sources such as CGM, SFM and DDGS could improve broiler production and at the same time improve the economy of poultry production. In this respect, various studies revealed that using different protein sources in broiler diets has a positive effect on their performance and meat quality (Aftahi et al., 2006; and Kermanshahi and Rostami, 2006). Meanwhile, there is a possible range of alternative feed ingredients that has been identified and potential for partially or fully replace soybean protein in broiler diets (Leeson, 2012).

CGM is a by-product of the manufacture of corn starch (and other times ethanol) by the wet-milling process (RFA, 2008).As demonstrated by Waldroup (2000), CGM could be included in broiler diets up to $10 \%$ without impairing performance traits. However, Rose et al. (2003) found a significant increase in feed intake when broiler chicks were fed a diet containing $10 \%$ CGM. Along the same line, DDGS is a co-product that is produced during the production of corn-based ethanol (Rosentrater, 2006). It is an acceptablefeed ingredient used as an alternative to corn or soybean meal in poultry diets (Jung et al.,
2012). Batal and Dale (2003) suggested that the maximum level of DDGS up to $6 \%$ in starter diets and $12 \%$ in grower-finisher diets with a beneficial effect on the productive performance. Results of Choi et al. (2008) revealed that the maximum level of DDGS was $15 \%$ in broiler diets with no adverse effect on performance traits. In this respect, Khalifah (2011) indicated that the best level of DDGS in broiler diets was $20 \%$ without any adverse effect on performance traits. In line with above mentioned ingredients, SFM has been extensively used in broiler diets as a good protein source (Pinheiro et al., 2002). Results of Furlan et al. (2001) asserted that up to $15 \%$ of sunflower meal can be included in broiler feeds with no adverse effect on performance. Also Oliveira et al. (2007) and Araujo et al. (2011) concluded that the dietary inclusion of $15 \%$ SFM improves productive performance, but does not affect carcass yield.

Because of the information scarcity on the possibility of using mixture of different protein sources in broiler finisher diets, the aim of the current study was to evaluate the effect of CGM (2.5\%), SFM (5\%) and DDGS $(7.5 \%)$ mixture in broiler finisher diets contained different levels of crude protein $(21,20$ and $19 \%)$ with a constant metabolized energy (3100 kcal ME/kg) on performance and carcass traits of Cobb 500 broiler chicks.

\section{MATERIALS AND METHODS}

The experimental work was carried out at Ismailia/Misr Company poultry farms Sarapium district, Ismailia in official collaboration with Poultry Production Department, Faculty of Agriculture, Alexandria University.

\section{Dietary treatments}

Diets were developed for super starter phase (0-8 days) with $23 \%$ crude protein (CP), starter phase (9-18 days) with $22 \%$ $\mathrm{CP}$ and at finisher phase (19-35 days). Birds were distributed into six treatments as follows: 1) control $21 \% \mathrm{CP}, 2$ ) tested $21 \% \mathrm{CP}, 3$ ) control $20 \% \mathrm{CP}, 4)$ tested $20 \%$ 
CP, 5) control 19\% CP and 6) tested 19\% $\mathrm{CP}$. Control diets were based only on soybean meal (SBM) as a source of protein, while tested diets based on partial replacement of SBM with mix of (CGM, SFM and DDGS) at $(2.5,5$ and $7.5 \%$, respectively) beside SBM. Diets were formulated to contain $3000 \mathrm{kcal}$ of $\mathrm{ME} / \mathrm{kg}$ for super starter and starter diets and 3100 $\mathrm{kcal}$ of $\mathrm{ME} / \mathrm{kg}$ for finisher diets whether control or tested. All diets were supplemented with complete vitamin, trace mineral premixes, phytase, mixed enzymes, probiotics, anti-mycotoxin and coccidiostat obtained from commercial sources. Composition and calculated analysis of the diets used in this experiment were shown in Table (1)

\section{Birds, housing and management}

A total of 432 day-old broiler chicks (Cobb 500 strain) were weighed and randomly assigned into 6 groups and three replicate per group with 24 birds per replicate. Chicks were raised in a temperaturecontrolled room with cleaned and fumigated ground floor under similar managerial and hygienic conditions. An ambient temperature program was maintained at $33^{\circ} \mathrm{C}$ at placement till 4 days of age, $32^{\circ} \mathrm{C}$ from 5 to 9 days of age, $29^{\circ} \mathrm{C}$ from 10 to 14 days of age, $27^{\circ} \mathrm{C}$ from 15 to 23 days of age, $25^{\circ} \mathrm{C}$ from 24 to 28 days of age, $23^{\circ} \mathrm{C}$ from 28 to 35 days of age and the relative humidity was around $60 \%$. Diets of super starter phase were provided in the form of crumbles, whereas those of starter and finisher phases were in pellets form at 3 and $5 \mathrm{~mm}$, respectively. Also, water and feed were provided for ad-libitum consumption.

\section{Performance}

At the end of each feeding phase, number and weight of birds present in each replicate were recorded as well as the weight of remaining feed. Number, age and weight of birds died during the trial were recorded in order to calculate the daily livability percentage. On the basis of measurements, body weights gain (BWG), feed conversion ratio (FCR), and production efficiency factor (PEF) were calculated and corrected for livability percentage. The equation of PEF was reported by Lemme et al. (2006) as follows: $\mathrm{PEF}=($ final weight, $\mathrm{kg} *$ livability \%)/(age, days* FCR)* 100 .

\section{Carcass traits}

At the end of the trial (35 days), five broilers from each dietary treatment were subjected to a total feed withdrawal of $12 \mathrm{~h}$. and slaughtered in a commercial slaughter house. In that, broilers were hung by their feet in steel shackles by hand then they were slaughtered by cutting the jugular veins of the neck according to the Islamic religion instruction with a sharp knife. When complete bleeding was achieved, birds were scalded, defeathered, and manually eviscerated. Carcasses, breast, thigh, fillet, tender, thigh meat, abdominal fat, wings and skin were calculated as a percentage relative to live body weight.

\section{Feed Cost and Cost Index}

The economical feasibility of the dietary inclusion of alternative protein sources mixture was assessed first by calculating feed cost per kilogram of body weight gain (Yi), as proposed by Bellaver et al. (1985). $\mathrm{Yi}=\left(\mathrm{Pi}{ }^{*} \mathrm{Qi}\right) / \mathrm{Wi}$

Where;

Yi: feed cost per kilogram of body weight gain in treatment

Pi: price per kilogram of feed used in treatment

Qi: feed intake amount in treatment

Wi: weight gain of treatment.

Then, the Economical Efficiency Index (EEI) and the Cost Index (IC) sorted by Fialho et al. (1992) were calculated.

$\mathrm{EEI}=(\mathrm{MCe} / \mathrm{CTei}) * 100$

$\mathrm{CI}=(\mathrm{CTei} / \mathrm{MCe})^{*} 100$

Where;

MCe: is the lowest feed cost per kilogram of weight gain observed among treatments CTei: cost of treatment. 
Khalifah, M. A. et al.

\section{Statistical analysis}

A completely randomized design was applied to execute this experiment. According to SPSS, 17 (2008), biological data of weight gain, feed intake and feed/gain ratio, and other data were subjected to statistical analysis by analysis of variance and the means were separated if they were significantly different using Duncan Multiple range test (Duncan, 1955).

The statistical model used was as follows:

$\mathrm{Y}_{\mathrm{ijk}}=\boldsymbol{\mu}+\mathrm{D}_{\mathrm{i}}+\mathrm{e}_{\mathrm{ij}}$

Where:

Yijk = Observed value of the dependent variable.

$\mu=$ Overall mean.

$\mathrm{D}=$ the effect of diets

$\mathrm{e}_{\mathrm{ij}}=$ The experimental random error.

\section{RESULTS}

\section{Performance}

Data of growth performance traits are presented in Tables (2 and 3). It is clearly shows that body weight of all experimental broiler chicks at 18 days old ranged from $537 \mathrm{~g}$ and $563.33 \mathrm{~g}$ with no significant difference among groups of studied dietary treatments. This created a suitable condition to appraise the effect of studied dietary treatments. With feeding experimental diets up to age of 35 days, no significant difference was detected in body weight among chicks fed the control or tested diets with alternate mixture at levels of 21 and $20 \%$ CP. Meanwhile, there is a tendency to decrease values of body weight with feeding tested diets under the same levels of protein. The opposite was true with dietary protein level of $19 \%$, where chicks of tested dietary treatment had higher weight but without significant difference. Along the same line, similar trend was detected with values of BWG through the growth period of (19-35 days). In that, BWG was decreased as feeding tested dietary treatment and decreasing levels of protein up to $20 \%$ but with no significant different with the control diets. Also, chicks fed control diet with $19 \%$ protein had lower BWG which recorded $1054.40 \mathrm{~g}$ compared with those fed tested diet at $19 \%$ protein which recorded $1105.00 \mathrm{~g}$ but without significant difference.

Concerning the amount of feed intake during finisher period it is obvious that the highest amount of feed was recorded by broiler chicks fed tested diet at $21 \%$ protein, $2171.81 \mathrm{~g}$, whereas the least amount was consumed by birds received the control diet of $19 \%$ protein followed by those of the tested dietary treatment of $19 \%$ protein. However, no significant difference was found among control and tested dietary treatments groups of 21 and $20 \%$ protein. Also, it is worthily noted that chicks of dietary treatment contained the studied mixture of (CGM, SFM and DDGS) with $19 \%$ protein consumed more feed than those of the corresponding control diet. Based on the above mention results, changes in average FCR during studied period shows that chicks fed the control diet at $21 \%$ protein recorded significantly the best FCR compared to those of the other studied dietary treatments, meanwhile, no significant difference was attained with chicks received tested diets of $21 \%$ and those of control and tested diets contained 20 or $19 \%$ protein. It is worth noted that feeding control diet of $21 \%$ protein give the best score in this respect. Regarding to the livability percentage throughout the finisher period, it appeared that no significant differences among all studied dietary treatment whether control or tested were found. Meanwhile, the highest percentage was recorded by chicks received the tested diet of $19 \%$ protein being $95.65 \%$, whereas the least value was attained with those fed control diets of $19 \%$ protein, being $93 \%$. Concerned results of $\mathrm{PEF}$ at the end of the trial, no significant difference was found between birds fed dietary treatments of 21 and $20 \%$ protein whether control or tested diets. Meanwhile, 
there is a tendency to decrease PEF with using low levels of dietary protein and incorporating CGM, SFM and DDGS mixture into diets, the opposite was true with chicks fed $19 \%$ protein where PEF of tested diet recorded higher value than those of control ones but without significant difference.

\section{Carcass traits}

Data concerning carcass traits of broiler chicks at 35 days of age are expressed as average of carcass, breast, thigh, wings, skin, abdominal fat, breast fillet, tender and thigh meat (percentage of live body weight) are summarized in (Table 4 and 5). No significant difference was observed among experimental groups regarding to the carcass, breast, thigh and abdominal fat. Meanwhile, feeding tested dietary treatment of $21 \%$ protein recorded higher percentage of carcass and lower percentage of abdominal fat being 75.90 and $0.97 \%$, respectively, whereas the opposite was seen with using tested diet of $19 \%$ protein being 73.82 and $1.09 \%$, respectively. On the other hand, chicks fed control diet contained $19 \%$ protein had significantly the highest percentage of wings being $7.81 \%$. This difference was disappeared with using the other dietary treatments. However, this trend was found with parameter of tender as shown in Table (5). As for skin and fillet percentage, no significant difference was detected among the experimental groups. Regarding to thigh meat percentage, no significant difference was found among chicks fed dietary treatments of 21 and $19 \%$ protein with or without studied mixture. Also, thigh meat of chicks received the control diet of $19 \%$ protein was statistically similar to those of the other studied dietary treatments of 21 and $20 \%$ protein. However, the highest percentage was recorded with chicks of tested dietary treatment of $21 \%$ protein and the lowest was recorded by chicks of tested diet of $19 \%$ protein.

\section{Feed cost and cost index}

Observing data (Table 6), it is obvious that there is a tendency to increase feed cost per weight gain as decreasing inclusion level of protein whether control or tested diets. However, tested diets of $21 \%$ protein scored less feed cost per kg gain being 4.75 L.E compared with the other dietary treatments. Assuming the feed cost per kg gain of broilers fed diet of $21 \%$ protein with mixture of CGM, SFM and DDGS as the lowest cost equal 100 , it is clearly shown that feeding this type of diet gave lower cost by $1.25 \%$ than the control diet at the same level.

\section{DISCUSSION}

Results of this study indicate that incorporating $15 \%$ of the studied mixture (2.5\% CGM, 5\% SFM and 7.5\% DDGS) as replacing for SBM into broiler Cobb 500 diets contained 21 and $20 \%$ protein with a constant metabolized energy (3100 $\mathrm{kcal} / \mathrm{kg}$ ) during finisher phase (19-35 days) can reduce growth performance numerically but not significant when compared to control diets. Such reduction in this respect may be due to non-starch polysaccharides (NSP) in the tested diets which causing some digestion problems for broiler chicks and reduce the absorption and availability of important nutrients (Annison and Choct, 1991; and Mostafa, 2009). However, this result was attained with the amount of feed consumed, livability, PEF and carcass yield. Based on the amount of feed intake and BWG, there is a tendency to impair feed conversion ratio significantly $(\mathrm{p} \leq 0.05)$ difference. Along the same line, Kamran et al. (2008) reported that an adverse effect was recorded for the productive performance of broilers but carcass traits were unaffected as feeding low protein diets with constant ME:CP ratio during period of (1-33 days of age). Also, Warren and Emmert (2000) suggested that using mixture of different ingredients with reduced protein content have no effect on body weight and feed 
Khalifah, M. A. et al.

intake of broilers. The opposite was true with dietary treatment of $19 \%$ protein, where an increase in all studied traits was recorded by chicks received the same level of protein with the tested diet. Such improvement in growth traits may be due to increasing feed intake by about $6.1 \%$ over the control. Meanwhile, no significance was seen in score of FCR. This result means that broilers had the ability to regulate the feed consumed based on the capacity limitation of the gastro-intestine for chicks (Scott, 2002). In addition, the increment in feed intake of tested diet of $19 \%$ protein may be due to the dietary inclusion of oil in SFM which may have improved digestibility of nutrients (Tavernari et al., 2008; and Araujo et al., 2011). As demonstrated by

Oliveira et al. (2007), dietary inclusion of $15 \%$ SFM improved performance traits, but did not affect carcass yield. Also, Kim et al. (2012) reported that fish or meat meal could be replaced by CGM in broiler diets without any adverse effect on their performance and carcass traits. In line with the previous findings, Min et al. (2012) found that inclusion of $30 \%$ DDGS had no adverse effect on gain, feed intake and FCR as well as breast meat yield. Results of economical efficiency show that experimental diet of $21 \%$ protein with CGM, SFM and DDGS mixture scored less feed cost per $\mathrm{kg}$ gain being 4.75 L.E. So, it could be concluded that incorporating mixture of corn gluten meal, sunflower meal and distillers dried grains with solubles into finisher diets had no adverse effect on the productive performance and carcass traits. In addition, a sustainable feeding program for finisher diets containing different alternative protein sources and levels could be applied to replace the traditional one.

\section{ACKNOWLEDGEMENT}

Special thanks to Dr. Mohamed El-Shafey, director manager of Ismailia/Misr Company for poultry production for supporting this research. 
Tabel (1): Composition and calculated analysis of diets used in the experiment

\begin{tabular}{|c|c|c|c|c|c|c|c|c|}
\hline \multirow{2}{*}{ Ingredients } & $\begin{array}{l}\text { Super } \\
\text { starter }\end{array}$ & Starter & \multicolumn{6}{|c|}{ Finisher phase } \\
\hline & $\begin{array}{l}\text { Control } \\
23 \%\end{array}$ & $\begin{array}{l}\text { Control } \\
22 \%\end{array}$ & $\begin{array}{l}\text { Control } \\
21 \%\end{array}$ & $\begin{array}{l}\text { Test } \\
21 \%\end{array}$ & $\begin{array}{l}\text { Control } \\
20 \%\end{array}$ & $\begin{array}{l}\text { Test } \\
20 \%\end{array}$ & $\begin{array}{l}\text { Control } \\
19 \%\end{array}$ & $\begin{array}{l}\text { Test } \\
19 \%\end{array}$ \\
\hline Yellow corn & 54.66 & 57.78 & 60.50 & 54.99 & 63.50 & 58.64 & 66.80 & 61.49 \\
\hline Soybean meal, $(48 \% \mathrm{CP})$ & 38.40 & 35.98 & 33.30 & 22.60 & 30.80 & 20.00 & 28.00 & 17.35 \\
\hline Corn gluten meal, $(62 \% \mathrm{CP})$ & - & - & - & 2.50 & - & 2.50 & - & 2.50 \\
\hline DDGS, $(31 \% \mathrm{CP})$ & - & - & - & 7.50 & - & 7.50 & - & 7.50 \\
\hline Sunflower meal, (28\% CP) & - & - & - & 5.00 & - & 5.00 & - & 5.00 \\
\hline Soy oil & 2.60 & 2.15 & 2.90 & 3.60 & 2.40 & 3.25 & 1.90 & 2.90 \\
\hline L-lysine HCL (98\%) & - & - & - & 0.050 & - & 0.15 & - & 0.25 \\
\hline DL-methionine (98\%) & 0.20 & 0.25 & 0.15 & 0.10 & 0.15 & 0.10 & 0.20 & 0.15 \\
\hline Limestone & 2.20 & 2.20 & 1.75 & 1.75 & 1.75 & 1.75 & 1.75 & 1.75 \\
\hline Di- calcium phosphate & 0.85 & 0.80 & 0.20 & 0.200 & 0.20 & 0.20 & 0.15 & 0.20 \\
\hline $\mathrm{NaCl}$ & 0.45 & 0.45 & 0.45 & 0.45 & 0.45 & 0.45 & 0.45 & 0.45 \\
\hline Vitamin premix $^{1}$ & 0.10 & 0.10 & 0.10 & 0.10 & 0.10 & 0.10 & 0.10 & 0.10 \\
\hline Mineral premix ${ }^{2}$ & 0.20 & 0.20 & 0.20 & 0.20 & 0.20 & 0.20 & 0.20 & 0.20 \\
\hline Coccidiostat $^{3}$ & 0.20 & 0.020 & 0.020 & 0.020 & 0.020 & 0.020 & 0.020 & 0.020 \\
\hline Mixed enzymes ${ }^{4}$ & 0.030 & 0.030 & 0.030 & 0.030 & 0.030 & 0.030 & 0.030 & 0.030 \\
\hline Anti-mycotoxin ${ }^{5}$ & 0.10 & 0.010 & 0.010 & 0.010 & 0.010 & 0.010 & 0.010 & 0.010 \\
\hline Phytase $^{6}$ & 0.0050 & 0.0050 & 0.0050 & 0.0050 & 0.0050 & 0.0050 & 0.0050 & 0.0050 \\
\hline Probiotic $^{7}$ & 0.0060 & 0.0060 & 0.0060 & 0.0060 & 0.0060 & 0.0060 & 0.0060 & 0.0060 \\
\hline Total & 100 & 100 & 100 & 100 & 100 & 100 & 100 & 100 \\
\hline \multicolumn{9}{|l|}{ Calculated analysis : } \\
\hline $\mathrm{ME},(\mathrm{kcal} / \mathrm{kg})$ & 3000 & 3000 & 3100 & 3100 & 3100 & 3100 & 3100 & 3100 \\
\hline Crude protein, $(\%)$ & 23 & 22 & 21 & 21 & 20 & 20 & 19 & 19 \\
\hline Fat, $(\%)$ & 2.60 & 2.67 & 2.75 & 3.4 & 2.85 & 3.48 & 2.94 & 3.57 \\
\hline Fiber, $(\%)$ & 2.49 & 2.47 & 2.45 & 3.97 & 2.44 & 3.95 & 2.43 & 3.94 \\
\hline Calcium, $(\%)$ & 1.10 & 1.10 & 0.77 & 0.76 & 0.77 & 0.76 & 0.75 & 0.75 \\
\hline Available Phosphorus, (\%) & 0.50 & 0.53 & 0.38 & 0.38 & 0.40 & 0.40 & 0.39 & 0.42 \\
\hline Total Lysine, $(\%)$ & 1.30 & 1.28 & 1.05 & 1.05 & 1.13 & 1.20 & 1.01 & 1.04 \\
\hline Methionine, $(\%)$ & 0.57 & 0.59 & 0.45 & 0.51 & 0.48 & 0.49 & 0.49 & 0.50 \\
\hline Cysteine, (\%) & 0.33 & 0.35 & 0.28 & 0.32 & 0.28 & 0.30 & 0.28 & 0.31 \\
\hline Meti+cyst, (\%) & 0.90 & 0.94 & 0.73 & 0.83 & 0.76 & 0.79 & 0.77 & 0.81 \\
\hline Arginine, $(\%)$ & 1.33 & 1.35 & 1.07 & 1.00 & 1.06 & 1.02 & 1.03 & 1.04 \\
\hline
\end{tabular}

${ }^{1}$ Vitamin premix provides per kg of diet: Vit. A: $12000000 \mathrm{IU}$, Vit. E: $400000 \mathrm{mg}$, Vit. Bl: $2000 \mathrm{mg}$. Vit. B2: 160000 mg, Vit. B6: 5000 mg, Vit, B12: 12 mg, Niacin: 45000 mg, Pantothenic acid: 12000 mg, Vit. K: 3000 mg, Vit. D3: 300000 IU, Biotin: 70 mg and Folic acid: $2000 \mathrm{mg}$.

${ }^{2}$ Trace mineral premix provides per $2 \mathrm{~kg}$ of diet: Choline: $3600000 \mathrm{mg}$, Copper: $10000 \mathrm{mg}$, Iodine: $1000 \mathrm{mg}$, Iron: $30000 \mathrm{mg}$, Manganese: $100000 \mathrm{mg}$, Zinc: $600000 \mathrm{mg}$, selenium: $400 \mathrm{mg}$, and cobalt: $100 \mathrm{mg} .{ }^{3}$ Diclazuril $500 \mathrm{mg}$,Atozuril ${ }^{\circledR}$ (ATcopharma). ${ }^{4}$ Combo ${ }^{\circledR}$ Enzyme Blend consists of : Cellulase $75,000 \mathrm{CU}$ units $/ \mathrm{kg}$, Fungal amylase 30,000 SKB units/kg, Fungal protease 1,000,000 HUT units/kg, Neutral protease 100,000 PC units/kg, Alkaline protease 1.2 Anson units/kg, Xylanase 20,000 XU units $/ \mathrm{kg}$, Beta-glucanase 20,000 BG units/kg, Hemicellulase 20,000 HCU units $/ \mathrm{kg}$ and Lipase 75,000 FIP units $/ \mathrm{kg}$.

${ }^{5}$ Mycofix ${ }^{\circledR}$ Select 3 , feed additives that protect broiler health by deactivation of mycotoxins. ${ }^{6}$ Axtra ${ }^{\circledR}$ PHY 10000 TPT, 6-phytase 10000 FTU/g. ${ }^{7}$ Enviva ${ }^{\circledR}$ Pro 202 GT, Bacillus subtilis 2.5E CFU/gm. 
Khalifah, M. A. et al.

Table (2): Body weight and body weight gain of broiler chicks fed finisher diets contained alternative protein sources at levels (21,20 and 19\%p)

\begin{tabular}{|l|c|c|c|c|c|c|}
\hline \multirow{3}{*}{ Treatments } & \multicolumn{4}{|c|}{ Body weight (g) } & \multicolumn{2}{c|}{ Body weight gain (g) } \\
\cline { 2 - 7 } & $\begin{array}{c}\text { Body weight18 } \\
\text { days }\end{array}$ & Body weight 35 days & $\begin{array}{c}\text { Finisher phase } \\
(19-35) \\
\text { days }\end{array}$ \\
\cline { 2 - 7 } & Mean & SE & Mean & SE & Mean & SE \\
\hline Control 21\%CP & 563.33 & 11.51 & $1888.75^{\mathbf{a}}$ & 23.99 & $1325.42^{\mathbf{a}}$ & 33.18 \\
Tested 21\% CP & 561.25 & 11.31 & $1840.67^{\mathbf{a}}$ & 25.81 & $1279.42^{\mathbf{a}}$ & 29.14 \\
Control 20\%CP & 537.00 & 5.83 & $1825.24^{\mathbf{a}}$ & 18.72 & $1288.24^{\mathbf{a}}$ & 21.23 \\
Tested 20\% CP & 543.33 & 4.18 & $1779.58^{\mathbf{a}}$ & 30.11 & $1236.25^{\mathbf{a}}$ & 31.43 \\
Control 19\%CP & 546.25 & 10.65 & $1600.64^{\mathbf{b}}$ & 42.60 & $1054.39^{\mathbf{b}}$ & 46.37 \\
Tested 19\% CP & 552.50 & 9.55 & $1657.50^{\mathbf{b}}$ & 63.31 & $1105.00^{\mathbf{b}}$ & 63.73 \\
\hline \multicolumn{7}{|c|}{ Test of significant } \\
\hline Treats
\end{tabular}

$(a, b)$ Means with no common superscripts are significantly different for each parameter

Table (3): Feed intake ( $\mathrm{g}$ ), feed conversion ratio ( $\mathrm{kg}$ feed/kg gain), livability and production efficiency factor of broiler chicks fed finisher diets contained alternative protein sources at levels $(21,20$ and $19 \%$ p)

\begin{tabular}{|c|c|c|c|c|c|c|c|c|}
\hline \multirow[t]{3}{*}{ Treatments } & \multicolumn{2}{|c|}{ Feed intake (g) } & \multicolumn{2}{|c|}{$\begin{array}{c}\text { Feed } \\
\text { conversion } \\
\text { ratio } \\
\text { (feed/gain) }\end{array}$} & \multicolumn{2}{|c|}{ Livability (\%) } & \multicolumn{2}{|c|}{$\begin{array}{c}\text { Production } \\
\text { efficiency factor } \\
(\%)\end{array}$} \\
\hline & \multicolumn{2}{|c|}{$\begin{array}{c}\text { Finisher phase } \\
(19-35) \text { days }\end{array}$} & \multicolumn{2}{|c|}{$\begin{array}{c}\text { Finisher phase } \\
(19-35) \text { Days }\end{array}$} & \multicolumn{2}{|c|}{$\begin{array}{c}\text { Finisher phase } \\
\text { (19-35 Days) }\end{array}$} & \multicolumn{2}{|c|}{$\begin{array}{l}\text { Total phase } \\
\text { (1-35 Days) }\end{array}$} \\
\hline & Mean & SE & Mean & SE & Mean & SE & Mean & SE \\
\hline Control 21\%CP & $2111.68^{a}$ & 35.60 & $1.60^{b}$ & 0.06 & 95.31 & 2.04 & $345.65^{a}$ & 13.60 \\
\hline Tested $21 \% \mathrm{CP}$ & $2171.81^{\mathrm{a}}$ & 18.66 & $1.70^{\mathrm{a}}$ & 0.05 & 95.06 & 2.18 & $320.54^{\mathrm{ab}}$ & 13.21 \\
\hline Control 20\%CP & $2169.88^{a}$ & 5.19 & $1.69^{\mathrm{a}}$ & 0.03 & 94.67 & 1.33 & $313.56^{\mathbf{a b c}}$ & 7.35 \\
\hline Tested 20\% CP & $2163.54^{\mathrm{a}}$ & 22.29 & $1.75^{\mathrm{a}}$ & 0.04 & 95.59 & 1.81 & $302.55^{\mathbf{a b c}}$ & 15.25 \\
\hline Control 19\%CP & $1824.69^{c}$ & 13.01 & $1.74^{\mathrm{a}}$ & 0.07 & 93.02 & 0.24 & $269.93^{c}$ & 14.45 \\
\hline Tested 19\% CP & $1936.24^{b}$ & 16.48 & $1.77^{\mathrm{a}}$ & 0.10 & 95.65 & 1.80 & $284.78 b^{\mathbf{c}}$ & 18.24 \\
\hline \multicolumn{9}{|c|}{ Test of significant } \\
\hline Treats & \multicolumn{2}{|c|}{ ** } & & & \multicolumn{2}{|c|}{$\mathrm{NS}$} & \multicolumn{2}{|l|}{$* *$} \\
\hline
\end{tabular}

NS: not significant $* \mathrm{p}<0.05^{* *} \mathrm{p}<0.01$

$(a, b)$ Means with no common superscripts are significantly different foreach parameter 
Alternative ingredients - Performance - Finisher diets - Carcass traits.

Table (4): Percentage of carcass, breast, thigh, abdominal fat and wings of broiler chicks fed finisher diets contained alternative protein sources at levels (21, 20 and 19\%p)

\begin{tabular}{|c|c|c|c|c|c|c|c|c|c|c|}
\hline \multirow[t]{2}{*}{ Treatments } & \multicolumn{2}{|c|}{ Carcass } & \multicolumn{2}{|c|}{ Breast } & \multicolumn{2}{|c|}{ Thigh } & \multicolumn{2}{|c|}{$\begin{array}{c}\text { Abdominal } \\
\text { fat }\end{array}$} & \multicolumn{2}{|c|}{ Wings } \\
\hline & Mean & SE & Mean & SE & Mean & SE & Mean & SE & Mean & SE \\
\hline Control 21\% CP & 75.13 & 0.40 & 35.86 & 0.39 & 29.07 & 0.93 & 0.98 & 0.01 & $7.12^{\mathbf{b}}$ & 0.12 \\
\hline Tested $21 \% \mathrm{CP}$ & 75.90 & 0.20 & 34.57 & 0.85 & 28.93 & 0.78 & 0.97 & 0.03 & $6.95^{\mathrm{b}}$ & 0.04 \\
\hline Control $20 \% \mathrm{CP}$ & 75.58 & 0.52 & 33.43 & 1.17 & 29.31 & 0.19 & 0.97 & 0.03 & $7.11^{\mathrm{b}}$ & 0.13 \\
\hline Tested $20 \% \mathrm{CP}$ & 75.21 & 0.52 & 35.00 & 0.29 & 28.19 & 0.48 & 0.99 & 0.02 & $6.87^{b}$ & 0.18 \\
\hline Control $19 \% \mathrm{CP}$ & 75.72 & 0.66 & 35.12 & 0.65 & 28.56 & 0.37 & 1.02 & 0.04 & $7.81^{\mathrm{a}}$ & 0.18 \\
\hline Tested $19 \% \mathrm{CP}$ & 73.82 & 0.54 & 34.79 & 0.43 & 27.07 & 0.94 & 1.09 & 0.04 & $6.94^{\mathrm{b}}$ & 0.26 \\
\hline \multicolumn{11}{|c|}{ Test of significant } \\
\hline Treats & \multicolumn{2}{|c|}{ NS } & \multicolumn{2}{|c|}{ NS } & \multicolumn{2}{|c|}{$\mathrm{NS}$} & \multicolumn{2}{|c|}{$\mathrm{NS}$} & \multicolumn{2}{|c|}{$* *$} \\
\hline
\end{tabular}

NS: not significant $* * \mathrm{p}<0.01$

$(a, b)$ Means with no common superscripts are significantly different for each parameter

Table (5): Percentage of fillet, tender, thigh meat and skin of broiler chicks fed finisher diets contained alternative protein sources at levels $(21,20$ and 19\%p)

\begin{tabular}{|c|c|c|c|c|c|c|c|c|}
\hline \multirow{2}{*}{ Treatments } & \multicolumn{2}{|c|}{ Fillet } & \multicolumn{2}{|c|}{ Tender } & \multicolumn{2}{|c|}{ Thigh meat } & \multicolumn{2}{|c|}{ Skin } \\
\hline & Mean & SE & Mean & SE & Mean & SE & Mean & SE \\
\hline Control 21\%CP & 17.80 & 0.33 & $2.91^{b}$ & 0.27 & $14.49^{\mathrm{a}}$ & 0.23 & 5.40 & 0.26 \\
\hline Tested $21 \% \mathrm{CP}$ & 17.03 & 0.28 & $2.87^{\mathbf{b}}$ & 0.11 & $14.63^{\mathrm{a}}$ & 0.45 & 5.44 & 0.39 \\
\hline Control 20\%CP & 17.21 & 0.59 & $3.21^{\mathrm{b}}$ & 0.08 & $14.23^{\mathrm{a}}$ & 0.19 & 6.20 & 0.56 \\
\hline Tested $20 \% \mathrm{CP}$ & 16.01 & 0.29 & $3.14^{\mathrm{b}}$ & 0.09 & $14.27^{\mathrm{a}}$ & 0.22 & 5.52 & 0.20 \\
\hline Control 19\%CP & 16.68 & 0.58 & $3.76^{\mathrm{a}}$ & 0.15 & $13.87^{\mathbf{a b}}$ & 0.24 & 5.05 & 0.12 \\
\hline Tested $19 \% \mathrm{CP}$ & 16.50 & 0.56 & $3.20^{\mathbf{b}}$ & 0.13 & $13.19^{\mathbf{b}}$ & 0.28 & 5.02 & 0.27 \\
\hline \multicolumn{9}{|c|}{ Test of significant } \\
\hline Treats & \multicolumn{2}{|c|}{ NS } & \multicolumn{2}{|c|}{$* *$} & \multicolumn{2}{|c|}{$* *$} & \multicolumn{2}{|c|}{ NS } \\
\hline
\end{tabular}

NS: not significant $* * \mathrm{p}<0.01$

$(a, b)$ Means with no common superscripts are significantly different for each parameter 
Table (6): feed cost per kilogram of body weight gain (FC), economical efficiency index (EFI) and cost index (CI) of Cobb broilers fed starter diets wit 22\%p and diets containing alternative protein sources at levels (21, 20 and 19\%p) at (19-35) day of age

\begin{tabular}{|c|c|c|c|}
\hline Treatments & $\begin{array}{c}\text { Feed cost }(\mathbf{L . E} / \mathbf{k g} \\
\text { BW)* }\end{array}$ & $\begin{array}{c}\text { Economic efficiency } \\
\text { index, }(\boldsymbol{\%}) * *\end{array}$ & $\begin{array}{c}\text { Cost index, } \\
(\boldsymbol{\%}) * * *\end{array}$ \\
\hline Control 21\% CP & 4.81 & 98.75 & 101.25 \\
Tested 21\% CP & 4.75 & 100 & 100 \\
Control 20\% CP & 4.91 & 96.74 & 103.36 \\
Tested 20\% CP & 4.91 & 96.74 & 103.36 \\
Control 19\% CP & 4.87 & 97.53 & 102.47 \\
Tested 19\% CP & 4.95 & 95.95 & 104.05 \\
\hline
\end{tabular}

*Feed cost $=$ (price per kilogram of feed used in treatment *feed intake in treatment)/ weight gain of treatment.

$* *$ Economical efficiency $=$ (lowest feed cost per kilogram of weight gain among treatment/ cost of treatment)*100.

$* * *$ cost index $=$ (cost of treatment/ lowest feed cost per kilogram of weight gain among treatment)*100. 


\section{REFERENCES}

Aftahi, A.; Munim, T.; Hoque, M. A.; and Ashraf, M. A., 2006. Effects of yoghurt and protexin boost on broiler performance. Int. J Poult. Sci., 5: 651655.

Annison, G.; and Choct, M., 1991. Antinutritional activities of cereal nonstarch polysaccharides in broiler diets and strategies minimizing their effects. World's Poult. Sci. J., 47: 232-241.

Araujo, L.F.; Araujo, C. S. S.; Petroli, N. B.; Laurentiz, A. C.; Albuquerque, R.; and Neto, M. A. T., 2011. Sunflower meal for broilers of 22 to 42 days of age. Revista Brasileira de Zootecnia, 40(10): 2142-2146.

Batal, A.; and Dale, N., 2003. Mineral composition of distillers dried grains with solubles. J. Appl. Poult. Res., 12: 400-403.

Bellaver, C.; Fialho, E. T.; Protas, J. F. S.; and Gomes, P. C., 1985. Radcula de maltena alimentaço de sunosem crescimento terminaço. Pesquisa Agropecuria Brasileira, 20(8): 969-974.

Chinrasri, A., 2004. Poultry Production Technology. Apichart Printing Press, Mahasarakam Province, Thailand. p: 206.

Choi, H. S.; Lee, H. L.; Shin, M. H.; Cheorun, J. O.; Lee, S. K.; and Lee, B. D., 2008. Nutritive and economic value of corn distillers dried grains with solubles. Asian-Aust. J. Anim. Sci., 21: 414-419.

Duncan, D. B., 1955. Multiple range and multiple F test. Biometrics, 11: 1-42.

Fialho, E. T.; Barbosa, O.; Ferreira, A. S.; Gomes, P. C.; and Girotto, A. F., 1992. Utilizaço da cevada suplementada com leo de soja para sunosem crescimento terminaço. Pesquisa
Agropecuria Brasileira, 27(10): 14671475.

Furlan, A. C.; Mantovani, C.; Murakami, A. E.; Moreira, I.; Scapinello, C.; and Martins, E. M., 2001. Utilizaço do farelo de girassolna alimentaço de frangos de corte. Revista Brasileira de Zootecnia; 30(1): 158164.

Hwangbo, J.; Hong, E. C.; Jang, A.; Kang, H. K.; Kim, B. W.; and Park, B. S., 2009. Utilization of house flymaggots, a feed supplement in the production of broiler chickens. J. Environ. Biol., 30: 609-614.

Jung, B.; Mitchell, R. D.; and Batal, A. B., 2012. Evaluation of the use of feeding distillers dried grains with solubles in combination with canola meal on broiler performance and carcass characteristics. J. Appl. Poult. Res., 21: 776-787.

Kamran, Z.; Sarwar, M.; Nisa, M.; Nadeem, M. A.; Mahmood, S.; Babar, M. E.; and Ahmed, S., 2008. Effects of low protein diets having constant energy to protein ration on performance and carcass characteristics of broiler chickens from one to thirty-five days of age. Poult. Sci., 87: 468-474.

Kermanshahi, H.; and Rostami, H., 2006. Influence of supplements dried mealworms on broiler performance and Cecal Flora. Int. J. Poult. Sci., 5(6): 538543.

Khalifah, A. M., 2011. Effect of using distillers dried grains with solubles plus commercial enzymes on productive performance of broiler chickens. M.Sc. Thesis., Poultry production Dept., Faculty of Agric., Alex. Univ., Egypt.

Kim, E. J.; Utterback, P. L.; and Parsons, C. M., 2012. Comparison of amino acid digestibility coefficients for corn, corn gluten meal, and corn distillers dried grains with soluble 
Khalifah, M. A. et al.

among 3 different bioassays. Poult. Sci., 91: 3141-3147.

Leeson, S., 2012. Future considerations in poultry nutrition. Poult. Sci., 91: 12811285.

http://dx.doi.org/10.3382/ps.201202373

Lemme, A.; Frackenpohl, U.; Petri, A.; Meyert, H., 2006. Response of male BUT big 6 turkeys to varying amino acid feeding programs. Poult. Sci., 85: 652-660.

Min, Y. N.; Li, L.; Waldroup, P. W.; Niu, Z. Y.; Wang, Z. P.; Gao, Y. P.; and Liu, F. Z., 2012. Effects of dietary distillers dried grains with solubles concentrations on meat quality and antioxidant status and capacity of broiler chickens. J. Appl. Poult. Res., 21: 603611.

Mostafa, M. M., 2009. Nutritional evaluation of canola as feed ingredient for broiler diets. Ph.D. Thesis, Fac. of Agric., Ain Shams University.

Oliveira, J. P.; Arajo, L. F.; and Junqueira, O. M., 2007. Farelo de girassol com suplementaço enzimutica para frangos de corte. Anais da Conferência APINCO de Ciência e Tecnologia; Santos, So Paulo. Brasil. p. 45.

Pinheiro, J. W.; Fonseca, N. A. N.; Silva, C. A.; Cabrera, L.; Bruneli, F. A. T.; and Takahashi, S. E., 2002. Farelo de girassolna alimentaço de frangos de corte emdiferentesfases de desenvolvimento. Revista Brasileira de Zootecnia, 31(3): 1418-1425.

Rao, S. V. R.; Raju, M. V. L. N.; Panda, A. K.; and Reddy, M. R., 2006. Sunflower seed meal as a substitute for soybean meal in commercial broiler chicken diets. Br. Poult. Sci., 47(5): 592-598.
RFA, 2008. Feeding the future: the role of the US ethanol industry in food and feed production. Renewable Fuels Association, Washington DC, USA

Rose, S. P.; Pirgozliev, V. R.; Countney, J.; and Hare, S. D., 2003. dietary protein source and lysine balance on the efficiency of energy utilization in broiler chickens. International symposioum, rostockwarnemunde, germany. pp: 227 230.

Rosentrater, K. A., 2006. Physical properties of distillers dried grains with solubles (DDGS). Paper No. 006164. Am. Soc. Agric. Biol. Eng. Annu. Int. Meet., Portland, OR. Am. Soc. Agric. Biol. Eng., St. Joseph, MI.

Scott, T. A., 2002. Impact of wet feeding wheat-based diets with or without enzyme on broiler chick performance. Canad. J. Anim. Sci., 82: 409-417.

SPSS, 2008. Statistical package for Social Sciences, version 17, SPSS Inc, U.S.A

Tavernari, F. C.; Albino, L. F. T.; and Morata, R. L., 2008. Inclusion of sunflower meal, with or without enzyme supplementation, in broiler diets. Revista Brasileira de Ciência Azcola, 10(4): 233-238.

Tolimir, N.; Peric, L.; Milosevic, N.; and Bogdanovic, V., 2010. The effect of multiphase nutrition on production performances of broilers. Biotec. Anim. Husb., 26(1-2): 83-91.

Waldroup, P. W., 2000. Present status of the use of digestible amino acid values in formation of broiler diets: opportunities and obstacles. AsianAust. J. Anim. Sci., 8: 7687.

Warren, W. A.; and Emmert, J. L., 2000. Efficacy of phase feeding in supporting growth performance of broiler chuck during the starter and finisher phases. Poult. Sci., 79: 764-770. 


$$
\text { الملخص العربى }
$$

الإستفادة من إستدامة العلف الناهي المحتوى على مصادر بليلة من البروتين ومختلف فى نسب الإبل

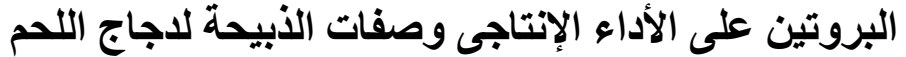

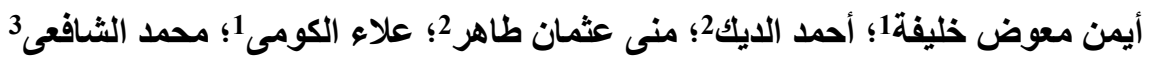

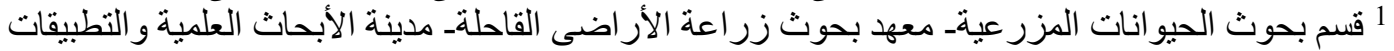

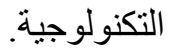

2 قسم إنتاج الدو اجنـ كلية الزر اعة الإنـ جامعة الاسكندرية.

3 شركة الإسماعيلية مصر لإنتاج الدواجن.

أجريت هذه التجربة لدر اسة تأثير استبدال كسب فول الصويا بخليط من كسب جلوتين الذرة، كسب عباد الثمس و النو اتج

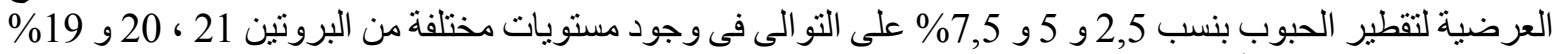

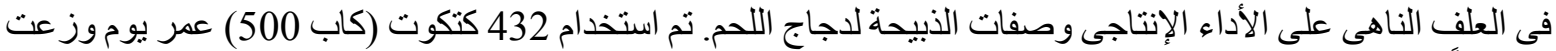

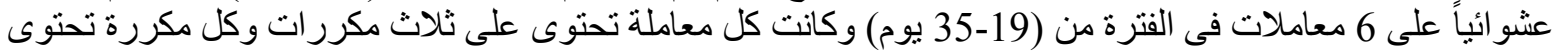
على 24 كتكوت وكانت المعاملات كما يلى : 1 1) كنترول 21\% \% بروتين، 4) مختبرة 20\% بروتين، 5) كنترول 19\% بروتين و 6 6) مختبرة 19\% برو

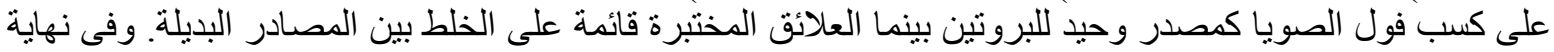

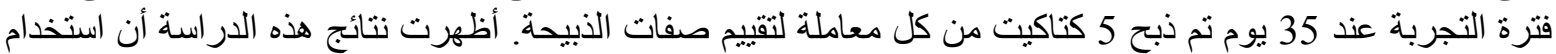

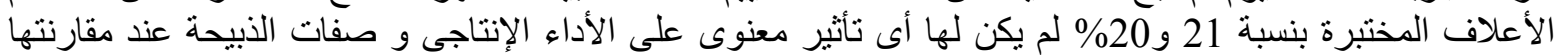

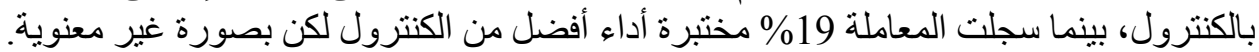

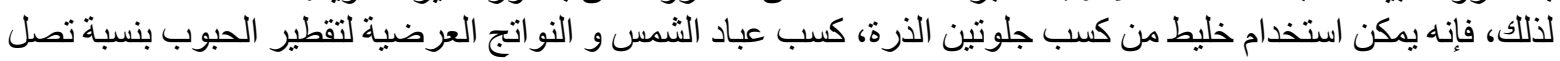

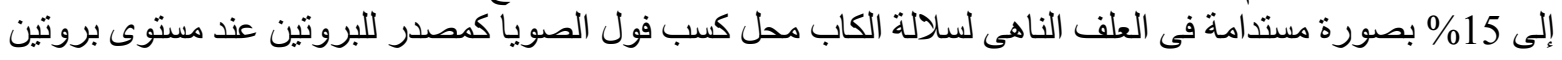

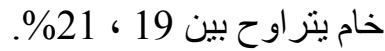

